\title{
Green House in Semi-arid Regions of Mexico
}

\author{
Maria de los Angeles Rechy Carvajal ${ }^{1}$, Emil von Roth ${ }^{2}$ and Jose Alberto Murillo Rodriguez ${ }^{3}$ \\ 1. Faculty of Forestry, Universidad Autónoma de Nuevo León, Linares, Nuevo León 67700, Mexico \\ 2. Aegis Structural Engineers, Studio City, California 91604, USA \\ 3. Universidad Autónoma de Nuevo León, Linares, Nuevo León 67700, Mexico
}

\begin{abstract}
The subject structure was consisted of a proto-type house with plan dimensions of $8 \mathrm{~m} \times 4 \mathrm{~m}$. A variety of materials was used to the construction, with special emphasis on using environmentally friendly non-toxic materials. The structure's core consisted of reinforced concrete frames with masonry infill walls. Inside faces of the walls and the roof's outside face were covered with proprietary composite panels, which are manufactured with a mixture of cement, volcanic ash, and local sawmill waste. These panels were analyzed for their physical and chemical properties, as well as for their resistance to decay and insects when subjected to extreme conditions for 15 years. The panels have also shown to provide thermal insulation and nonflammable when in direct contact with fire. The roof surface was further covered with a blend of local drought-resistant succulents and cacti. This study provides a detailed review of the construction process and materials employed.
\end{abstract}

Key words: Prototype house, thermal insulation, non-combustible, resistant to decay.

\section{Introduction}

The objective of this research was to develop a low-cost method to improve thermal insulation for houses located in the semi-arid Northeast of Mexico. This research was carried out in the city of Linares, in the state of Nuevo León, having the geographic coordinates: $20^{\circ} 50^{\prime} 16^{\prime \prime} \mathrm{N}$ and $99^{\circ} 32^{\prime} 41^{\prime \prime} \mathrm{W}$ (Fig. 1).

According to the Köppen-Geiger climate classification, the climate in this area is considered semi-arid $\left(\mathrm{BS}_{\mathrm{h}}\right)$. The average annual precipitation is $600 \mathrm{~mm} / \mathrm{m}^{2}$, dropping to an average of $400 \mathrm{~mm} / \mathrm{m}^{2}$ during dry years. Most of the precipitation takes place during the months of May and September. This climate has led to the formation of thorn savannahs (known as Matorral in the Spanish language).

The region where the study was performed is rural, which leads to the restriction of being limited to use locally available raw material. Automated production of lightweight pumice or wood concrete block stones is therefore not practically feasible.

A research project carried out at the Faculty of

Corresponding author: Maria de los Angeles Rechy Carvajal, professor, research field: forestry.
Forestry of the Universidad Autónoma de Nuevo León (Linares, Mexico) studied various locally available materials with the intent of identifying their suitability for thermal insulation purposes. Local availability and material cost led to the choice of wood concrete. This material is characterized by being nonflammable and highly resistant to biologically induced degradation.

\section{Materials}

\subsection{Traditional Clay Masonry Construction}

The traditional construction is clay masonry based with thatch or palm-leaf roofs. The clay masonry bricks employed have a density of $2 \mathrm{~g} / \mathrm{cm}^{3}$ and a thermal conductivity of $1.20 \mathrm{~W} /(\mathrm{m} \cdot \mathrm{K})$. Lighter straw clay bricks have a density of $1.6 \mathrm{~g} / \mathrm{cm}$ and a thermal conductivity of $0.80 \mathrm{~W} /(\mathrm{m} \cdot \mathrm{K})$. Such values do not allow for energy-saving construction. Additionally, clay construction requires constant maintenance to achieve good durability.

\subsection{Current Concrete Masonry Construction}

Hollow concrete masonry construction with reinforced concrete roofs has displaced the traditional building 


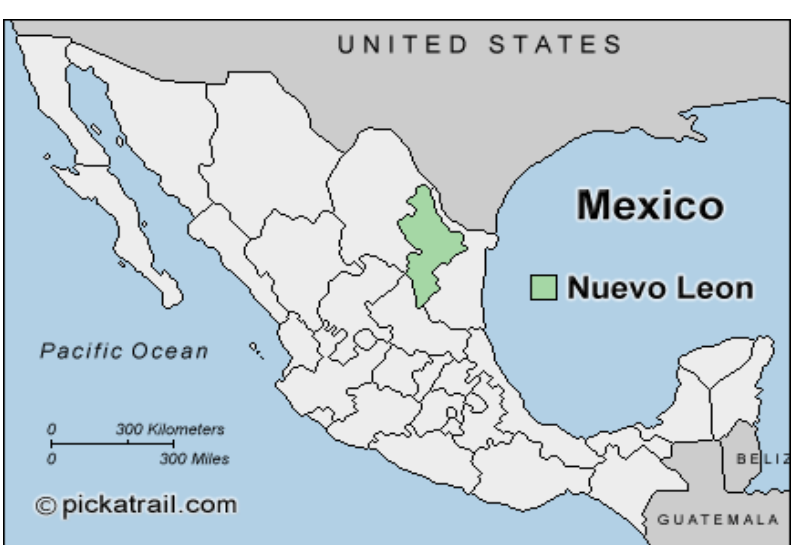

Fig. 1 Geographical location of the studied area.

method over the last few decades. This foster by the ease of construction, durability, and speed of construction. Concrete's thermal conductivity $\lambda$ is 2.1 $\mathrm{W} /(\mathrm{m} \cdot \mathrm{K})$. This results for $15 \mathrm{~cm}$ thick hollow concrete masonry blocks in a thermal conductivity $\lambda$ is 0.80 $\mathrm{W} /(\mathrm{m} \cdot \mathrm{K})$. As a result, the thermal isolation of today's homes in the region is not good. Thermal conductivity values are determined experimentally through hot plate tests (Fig. 2).

Without considering thermal boundary layers, the thermal resistance $\mathrm{R}_{\mathrm{w}} /\left(\mathrm{R}_{\mathrm{wall}}\right)$ for these walls is $0.15 / 0.80=0.19 \mathrm{~m}^{2} \cdot \mathrm{K} / \mathrm{W}$. A $12 \mathrm{~cm}$ thick roof has a

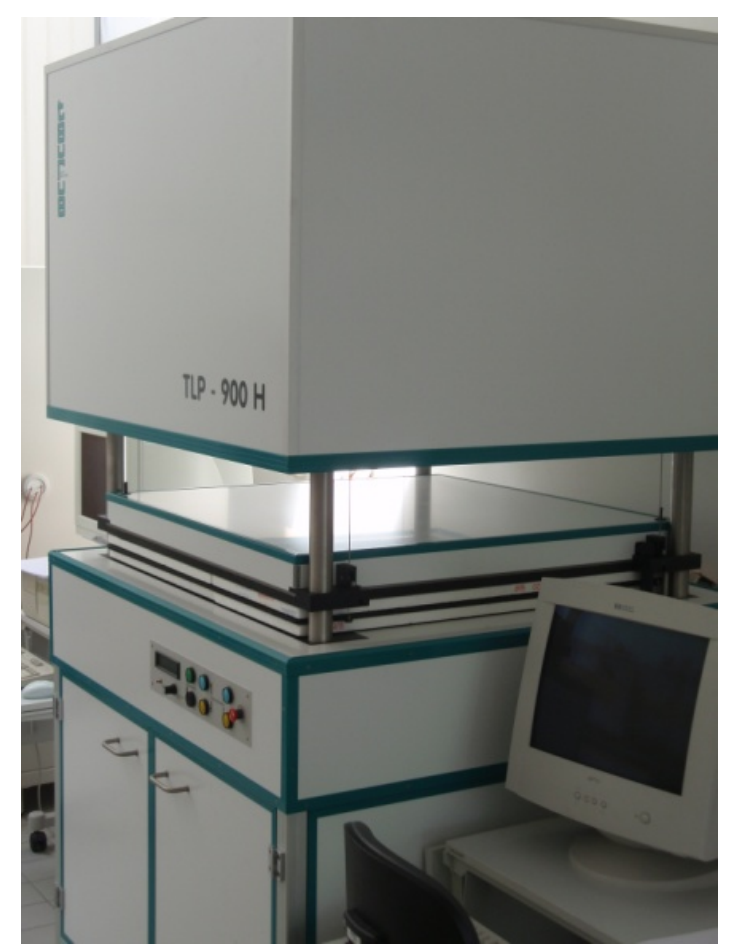

Fig. 2 Equipment for determination of heat transfer. thermal resistance of $\mathrm{R}_{\mathrm{r}} /\left(\mathrm{R}_{\mathrm{rof}}\right)=0.12 / 2.1=0.06$ $\mathrm{m}^{2} \cdot \mathrm{K} / \mathrm{W}$. These values are too low for habitable spaces in semi-arid regions given that minimum recommended R-values are $\mathrm{R}_{\mathrm{W}}=0.50 \mathrm{~m}^{2} \cdot \mathrm{K} / \mathrm{W}$ and $\mathrm{R}_{\mathrm{r}} 1.0 \mathrm{~m}^{2} \cdot \mathrm{K} / \mathrm{W}$ for walls and roofs respectively. Lack of thermal insulation makes these houses barely habitable, This leads to high costs related to cooling and heating.

Although high-density building materials typically exhibit high load capacities, they are also typical characterized by low thermal insulation properties.

\section{Construction Method Used}

\subsection{Wood Concrete as Insulating Material}

The previously mentioned research led to the selection of wood concrete as insulation material due to local availability and low-income wages. Wood chips needed for manufacture of this insulation material can be procured easily at low cost. A common concrete mixer (Fig. 3) can be used to mix the wood chips and cement. Manufacture of insulating wall panels is benefitted by the use of a hydraulic press or jack. Poured-in-place roof insulation can be compacted with a manual compactor.

\subsection{Installation of Thermal Insulation}

Installation of the insulation is relatively simple. Wall panels are adhered to the interior faces of the walls. At the roof, the insulating wood concrete layer is placed below and prior to pouring the load-carrying reinforced concrete plate.

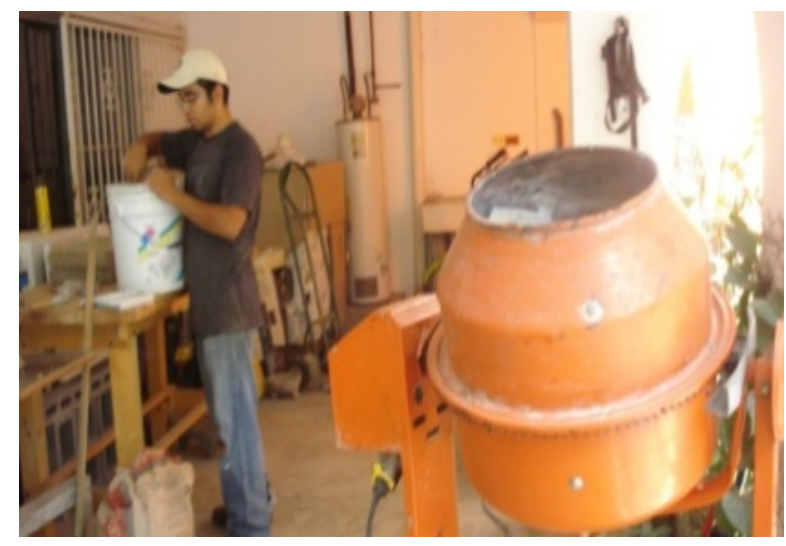

Fig. 3 Small concrete mixer. 


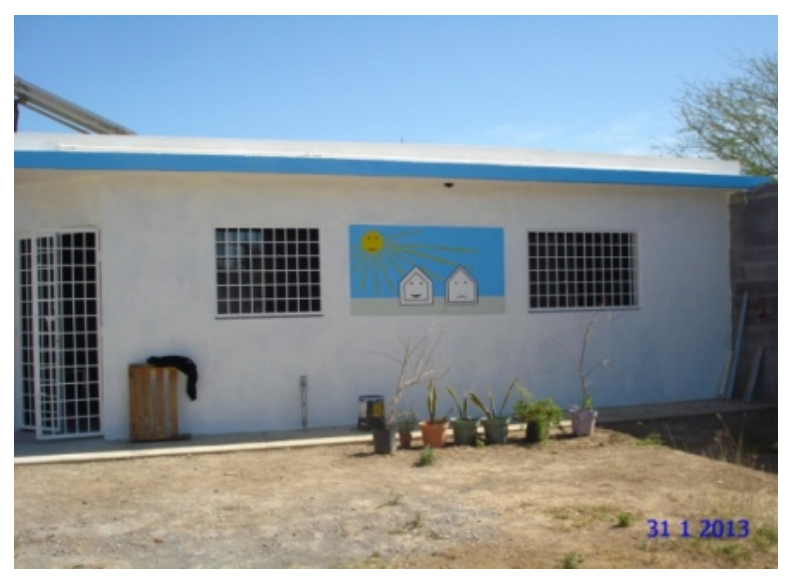

Fig. 4 Outside view of the prototype house.

A prototype house with an area of $4 \times 8 \mathrm{~m}$ was built to test the effectiveness of the wood concrete insulation material (Fig. 4). The walls were provided with $5 \mathrm{~cm}$ thick insulation panels adhered to the inside faces. The poured-inplace roof insulation thickness was $8 \mathrm{~cm}$. (Fig. 5). Average grade wood concrete (density $\rho=0.6$ $\mathrm{g} / \mathrm{cm}^{3}$ ) was used to allow for installation of normal household items (lamps, pictures, etc.).

\section{Results and Discussion}

The research results for wood concrete was performed following DIN 4108 and DIN EN 832 (2011), being shown in Table 1.

Thermal insulation for cooled and heated houses should provide at the exterior of the building in order to allow for thermal inertia of the heavy concrete construction to contribute to a balance of interior temperatures. In buildings that are not cooled and only heated when required, the thermal insulation should be provided at the interior in order to take advantage of the nocturnal fall of temperature during the Summer and of quick heating with minimized temperature loss during the Winter.

The thermal conductivity $\lambda$ of wood concrete is $0.16[\mathrm{~W} /(\mathrm{m} \cdot \mathrm{K})]$, thus resulting in a thermal resistance for the walls of $R_{\text {wall }}=0.15 / 0.80+0.05 / 0.16=0.50$ $\left[\mathrm{m}^{2} \cdot \mathrm{K} / \mathrm{W}\right]$ and for the roof of $\mathrm{R}_{\text {roof }}=0.12 / 2.1+$ $0.08 / 0.16=0.56\left[\mathrm{~m}^{2} \cdot \mathrm{K} / \mathrm{W}\right]$.

The insulation provided at the walls met the minimum requirement for habitable spaces. In contrast,
Table 1 Research results for wood concrete.

\begin{tabular}{lll}
\hline Density & Compression strength & Thermal conductivity \\
\hline$\left[\mathrm{g} / \mathrm{cm}^{3}\right]$ & $\mathrm{MPa}$ & $\mathrm{w} /(\mathrm{m} \cdot \mathrm{K})$ \\
$0.45-0.80$ & $1.50-2.10$ & $0.10-0.25$ \\
\hline
\end{tabular}

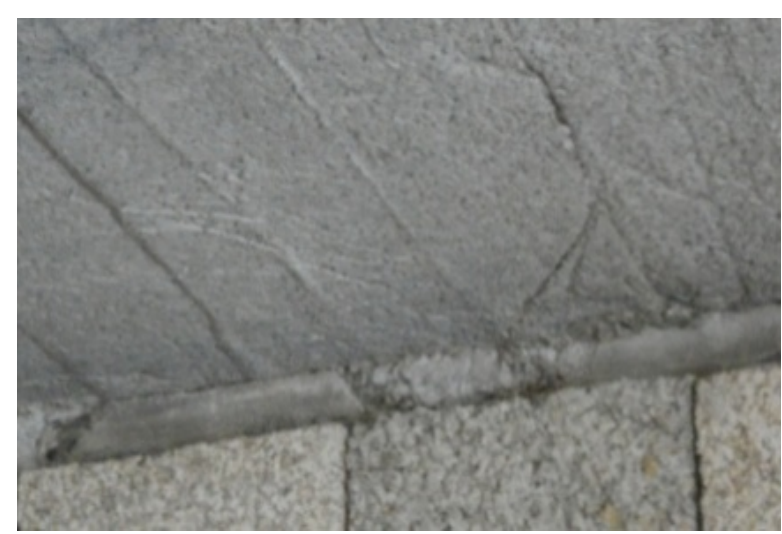

Fig. 5 Interior corner showing wall and roof interface.

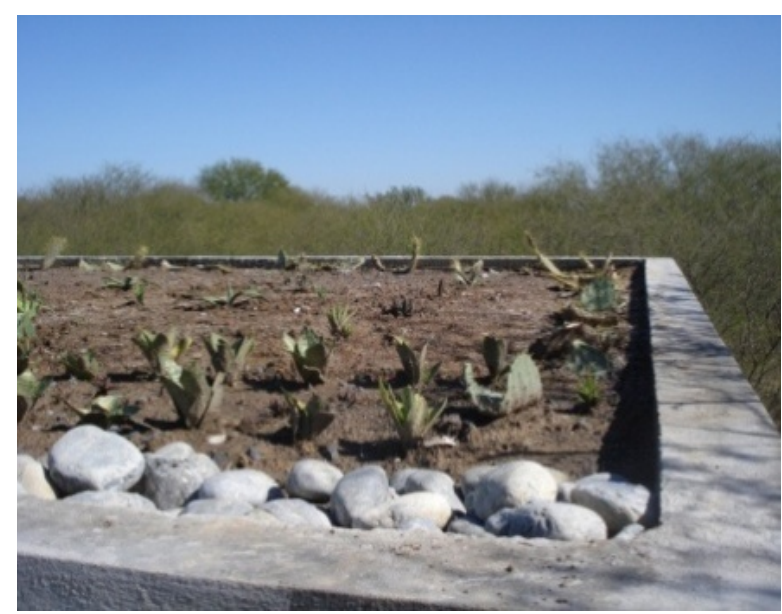

Fig. 6 Green roof with drought-resistant plants.

the insulation at the roof required improvement. This roof insulation improvement was achieved through a green roof insulation layer. Detailed quantitative information on the level of thermal insulation provided by the green roof was not available at time of this publication because of the large variability of green roof assemblies and the complexity of determining the thermal insulation achieved.

Permanent temperature controls at the interior and exterior surfaces showed an average temperature delta of close to $10{ }^{\circ} \mathrm{C}$ during summer months.

\section{Reference}

[1] Rechy, de. Von., Roth, M. d. 1. A. 2014. "Green 
House Construction." The International Conference on Dryland, Deserts and Desertification. Sede Boquer. Israel.

[2] Heyer, E. 1993. Witterung und Klima. Stuttgart: Teubner Verlag.

[3] Vermosen, G. 2008. Un Plastique Nature. Belgium: Vermosen-Bonheiden.

[4] Lohmeyer, G. C. O., Bergmann, H., Post, M. 2005.
Praktische Bauphysik. Germany: Teubner Verlag Stuttgart.

[5] Din 4108. 2015. Wärmeschutz in Hochbau. Berlin: Beuth Verlag.

[6] Proporowitz, H., Unruh, H. 2008: Baubetrieb-Bauverfahren. München: Hanser Verlag.

[7] Köhler, M., Barth, G., Brandwein, T. 1993. Fassadenbegrünung und Dachbegrünung. German: Verlag Eugen Ulmer. 